\title{
The effects of human resource management, customer satisfaction, organizational performance on tourism supply chain management
}

\author{
Tran Minh Nguyet ${ }^{a^{*}}$, Nguyen Van Dung ${ }^{a}$, Tran Thi Thu Trang ${ }^{a}$, Tran Tuan Anh ${ }^{a}$ and Nguyen Duc \\ Duong $^{\mathrm{a}}$
}

${ }^{a}$ Hanoi University of Natural Resources and Environment, Vietnam

\begin{tabular}{l}
\hline C H R O N I C L E \\
\hline Article history: \\
Received February 29, 2021 \\
Received in revised format May \\
20,2021 \\
Accepted June 92021 \\
Available online \\
June 92021 \\
\hline Keywords: \\
Human resource management \\
Customer satisfaction \\
Organizational performance \\
Supply chain management \\
Tourism supply chain
\end{tabular}
A B S T R A C T

\begin{abstract}
The goal of this research is to investigate the relationship between human resource management and tourism supply chain management, as well as the effects of human resource and tourism supply chain on customer satisfaction and operation performance. The research was carried out in Vietnam at several tourist destinations. The study found 297 viable samples after screening the sample. A Partial Least Squares (PLS) algorithm was used to process the data. The study's findings revealed a link between human resources and supply chain management in the tourism business. Furthermore, the study discovered that human resource management uncertainty had an impact on organizational performance.
\end{abstract}

\section{Introduction}

The integration of important business processes from suppliers to deliver value-added products, services, and information to end-users is known as supply chain management (Krmac, 2011). As a result, supply chain management has an important human component that promotes communication and cooperation among all parties involved in the supply chain (Power, 2005). Human resources and supply chain management are generally viewed as different topics of study, even though they are "intimately interwoven" in most company situations (Garanca, 2008). In fact, Taylor et al. (2010) presented human resource management as a new research topic in relation to the realm of activity. An effective human resource system is essential for establishing a supply chain, increasing customer happiness, and improving operational performance (Gunasekaran, 2004). A tourism supply chain is a network of different organizations and businesses that supply one or more components of tourism products/services, such as airline and lodging services, for the distribution and marketing of final tourism products and services in a tourist destination, and it involves multiple levels, industries, and participating businesses in both the public and private sectors (Zhang et al., 2009). Tourism supply chain management is the linking of processes in the tourism industry from initial providers (transportation, lodging, dining, sightseeing, and shopping while traveling) to end users (tourists) to give products, services, and information to them (Berger, 2002). The establishment and proper management of a tourist supply chain will aid in the maximization of benefits for all parties involved (the state, suppliers, tourism businesses, tourists, and local people in the tourism destination). calendar). This is also the problem of improving the quality of "tourist products" (Dinh, 2017). In 2020, vaccines, country tourism policy, the economy, and the environment will all have an impact on the tourism sector. Covid-19 has extended the influence of these repercussions on Vietnam's tourism business, contributing significantly to the development of the Vietnamese tourism trend in 2021.Prior to Covid-19, discovering a crowded city, meandering through lively marketplaces, dining with locals in pubs, and visiting appealing tourist attractions...

* Corresponding author

E-mail address: nguyettm1982@gmail.com (T. M. Nguyet)

(c) 2021 Growing Science Ltd. All rights reserved.

doi: $10.5267 /$ j.uscm.2021.6.005 
are all highly engaging experiences for Vietnamese travelers. Restrictions imposed during the epidemic season, on the other hand, have affected the way tourists travel. Travel in the direction of social distancing to adapt to the situation is expected to be a trend in 2021 (Corazza \& Musso, 2021).

Due to the impact of the epidemic, tourism activities have been greatly reduced, but according to statistics, the tourism industry in 2020 will still increase by $2.34 \%$ and contribute to Vietnam's GDP $33.5 \%$ compared to 2019 . According to Agoda site data, Vietnam is one of the four most attractive tourist destinations in 2020. Tourism, as a general economic sector, is forecast to suffer a lot of damage and may last even after the epidemic ends. Therefore, Vietnam must prepare plans to develop the tourism industry after the epidemic is controlled. The research will study the relationship between factors human resource, supply chain management, customer satisfaction, organizational performance to find out the influencing factors and propose options.

\section{Literature review}

\subsection{Tourism supply chain management}

Tourism is a multi-use sector that includes a variety of products and services (such as transportation and lodging) that are combined to create the ultimate tourism product (Buhalis et al., 2012). Because services cannot be saved for future use, travel products are not kept. Because tourism items cannot be tested before purchase and tourists must visit tourist producing locations to consume items, the tourism sector is a highly information-intensive industry (Khondker et al., 2015). As a result, the selling of tourism items is strongly reliant on the product's presentation and interpretation at the point of sale. Tourism products are classed and aggregated in general, and comprise various service components such as lodging, transportation, sightseeing, dining, and shopping (Divisekera, 2010). Due to fierce rivalry among service providers, the tourism business frequently experiences bigger demand variations and more complex dynamics than related businesses (Zhang et al., 2009).

The four dimensions are often used variables to represent tourism supply chain management such as (1) Order process management, (2) Relationship management (suppliers and customers), (3) Service performance management, and (4) Capacity and resources management (Y1lmaz et al., 2006; Palang et al., 2019).

\subsection{Human resource management}

The success of supply chain management is determined by the behavior of the personnel who make up the supply chain in the company. HRM, according to some authors, serves as a support and a mechanism for managing supply chain obligations and interactions. Menon (2012) discovered that certain HRM practices, such as flexible job descriptions, team organization, collaboration training, and the use of performance indicators, are strongly linked to supply chain success.

The four dimensions are often used variables to represent HRM such as (1) compensation \& benefits, (2) training \& staff development, (3) communication management style; and (4) recruitment and selection of employees (Smith-Doerflein et al., 2011; Hohenstein et al., 2014)

\subsection{Customer satisfaction}

According to Kotler (1999), satisfaction is defined as a person's experience of pleasure, excitement, delight, or disappointment because of comparing a product's perceived performance to their expectations. The level of satisfaction depends on the factors of service quality, product quality, price, and personal factors (Rizan, 2010; Asadi et al., 2014; Pappas, 2017).

\subsection{Organization performance}

Organizational performance refers to how successfully a company meets both its market-oriented and financial objectives (Munizu, 2013). The traditional approach of evaluating performance based solely on financial metrics is faulty. Several past studies have used financial and commercial factors to assess organizational effectiveness, such as return on investment (ROI), market share, and profit margin (Jarad, 2010; Munizu, 2013). The four dimensions are often used variables to represent organization performance such as (1) maker share, (2) return on investment, (3) profit margin on sales; and (4) overall competitive position. (Li et al., 2006)

Based on empirical studies and theories, the research hypotheses are:

H1: Human Resource Management has a positive effect on Tourism Supply Chain Management.

H2: Human Resource Management has a positive effect on Customer Satisfaction.

H3: Human Resource Management has a positive effect on Organization Performance.

H4: Tourism Supply Chain Management has a positive effect on Customer Satisfaction.

H5: Tourism Supply Chain Management has a positive effect on Organization Performance. 


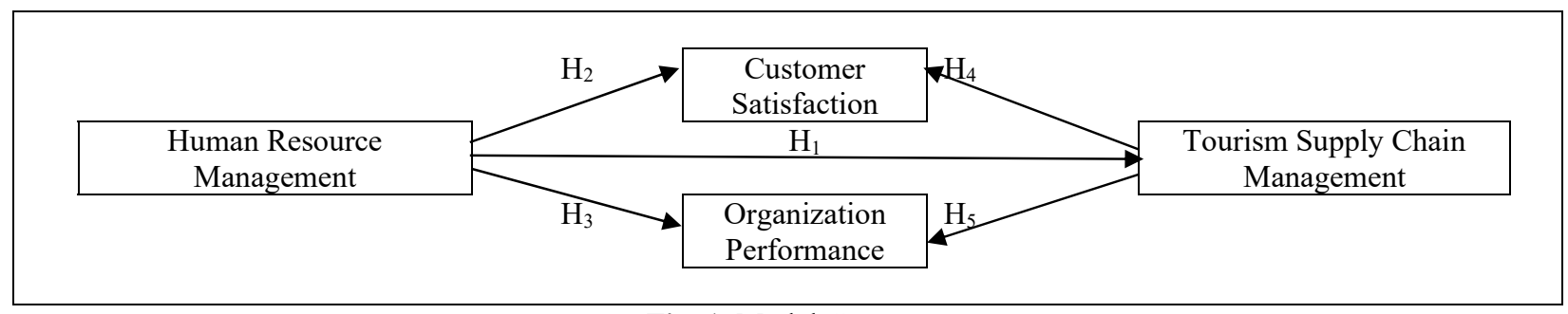

Fig. 1. Model Concept

\section{Methodology}

A structural equation modeling technique employing partial least squares (PLS) was employed to experimentally test the presented hypotheses (Wong, 2013). This methodology has proved particularly useful in multivariate analysis, and its application in the field of SCM has been expanded (Gimenez et al., 2005; Hazen et al., 2015). PLS is the most appropriate methodology for this research since it is a tool for performing predictive causal analysis (Soni et al., 2012; Chen et al., 2015) in circumstances with great complexity and low theoretical understanding. This is a case study in human resources and supply chain management.

According to Lakens (2014), 100 observations is sufficient to provide an acceptable level of statistical power. As a result, we conclude that our sample size is adequate for estimating the PLS, given the properties of our model. PLS yields more accurate route coefficient estimations when the sample size is less than 500 (Hazen et al., 2015).

We created an internet survey to measure the constructs, with responses graded on a five-point Likert scale $(1=$ Strongly Disagree; $5=$ Strongly Agree). We utilized the partial least squares approach to analyze these results statistically. We received 325 replies, with a total of 297 legitimate questionnaires after filtering the data. From January through April of 2020, surveys were sent out. This sample size is suitable for the model's conditions. The sample size must meet the so-called "rule of thumb" which states that the sample size must be at least ten times bigger than the number of predictors (Gefen et al., 2011).

\section{Results}

The results on the characteristics of the respondents are shown in Table 1 with $10,1 \%$ of the respondents are senior corporate executives (chairmen, CEOs, or managers), $45 \%$ are functional area directors (such as tourism logistics or human resources), and the rest work in intermediate positions (mainly related to tourism). According to the sample, $\%$ of the organizations have fewer than 100 employees, 36\% have between 100 and 500 employees, and 36\% have more than 500 employees.

Table 1

Characteristics of respondents

\begin{tabular}{clcc}
\hline Characteristics & \multicolumn{1}{c}{ Categories } & Frequency & Percentage (\%) \\
\hline Position & chairmen, CEOs, or managers & 30 & 10,1 \\
& directors & 80 & 26.9 \\
& Intermediate (staff) & 187 & 63 \\
\multirow{2}{*}{ Company size } & $\leq 50$ employees & 97 & 32.7 \\
& $50-150$ employees & 175 & 58.9 \\
& $\geq 150$ employees & 25 & 8.4 \\
& Ha Noi & 50 & 16.8 \\
& Lao Cai & 25 & 8.4 \\
& Hai Phong & 40 & 13.5 \\
& Thanh Hoa & 35 & 11.8 \\
& Quang Ninh & 28 & 9.4 \\
& Da Lat & 26 & 8.8 \\
& Da Nang & 28 & 9.4 \\
& Nha Trang & 25 & 8.4 \\
\end{tabular}

Testing the reliability test construct using composite reliability (CR), average variable extracted (AVE), and alpha a (AVE) is 0.50 or more (Hair et al., 2014) shown in Table 2. 
Table 2

Test of the validity and reliability

\begin{tabular}{|c|c|c|c|c|}
\hline Code & Variable & Factor's loading & t-value & VIF \\
\hline \multicolumn{5}{|c|}{ Human Resource Management (Cronbach's alpha: 0.901, CR: 0.931, AVE: 0.771) } \\
\hline HRM1 & Compensation \& benefits & 0.856 & 56.139 & 2.371 \\
\hline HRM2 & Training \& staff development & 0.881 & 61.224 & 2.569 \\
\hline HRM3 & Communication management style & 0.891 & 73.942 & 2.670 \\
\hline HRM4 & Recruitment and selection of employees & 0.884 & 63.251 & 2.711 \\
\hline \multicolumn{5}{|c|}{ Customer Satisfaction (Cronbach's alpha: 0.826, CR: 0.884, AVE: 0.656) } \\
\hline CS1 & Perceived price & 0.809 & 25.128 & 1.699 \\
\hline $\mathrm{CS} 2$ & Quality & 0.819 & 26.199 & 1.708 \\
\hline CS3 & Benefits & 0.805 & 24.143 & 1.725 \\
\hline CS4 & Prestige & 0.807 & 20.585 & 1.857 \\
\hline \multicolumn{5}{|c|}{ Organization Performance (Cronbach's alpha: 0.854, CR: 0.901, AVE: 0.695) } \\
\hline OP1 & Maker share & 0.820 & 31.413 & 1.836 \\
\hline OP2 & Return on investment & 0.832 & 34.362 & 1.861 \\
\hline OP3 & Profit margin on sales & 0.864 & 46.336 & 2.315 \\
\hline OP4 & Overall competitive position & 0.817 & 32.866 & 1.890 \\
\hline \multicolumn{5}{|c|}{ Tourism Supply Chain Management (Cronbach's alpha: 0.827, CR: 0.885, AVE: 0.659) } \\
\hline TSCM1 & Order process management & 0.803 & 31.939 & 1.737 \\
\hline TSCM2 & Relationship management & 0.824 & 42.990 & 1.875 \\
\hline TSCM3 & Service performance management & 0.803 & 36.437 & 1.701 \\
\hline TSCM4 & Capacity and resources management & 0.817 & 38.911 & 1.822 \\
\hline
\end{tabular}

So, the overall evaluation research model can be expressed well, and we can further proceed with the analysis of hypothesis testing.

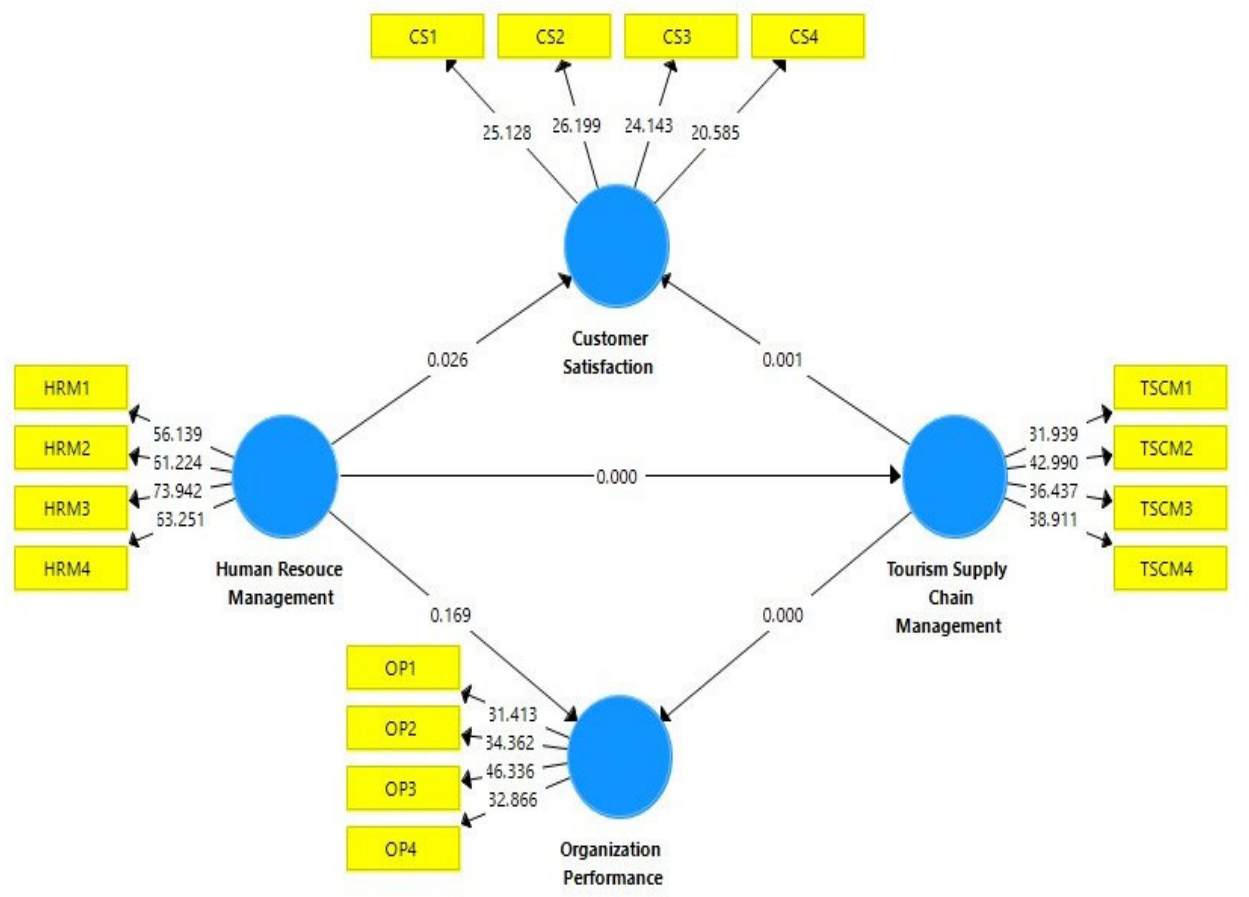

Fig 2. Bootstrapping Result

Table 3

Test Results Path Coefficient

\begin{tabular}{llcl}
\hline & \multicolumn{1}{c}{ Hypothesis Test } & P_value & Results \\
\hline H1 & Human Resource Management $\rightarrow$ Tourism Supply Chain Management & 0.000 & Supported \\
H2 & Human Resource Management $\rightarrow$ Customer Satisfaction & 0.026 & Supported \\
H3 & Human Resource Management $\rightarrow$ Organization Performance & 0.169 & Rejected \\
H4 & Tourism Supply Chain Management $\rightarrow$ Customer Satisfaction & 0.001 & Supported \\
H5 & Tourism Supply Chain Management $\rightarrow$ Organization Performance & 0.000 & Supported \\
\hline
\end{tabular}


Based on the results of the direct relationship analysis from Table 3, it indicates that the hypothesis ( $\mathrm{H} 3$ is rejected, H1, H2, $\mathrm{H} 4$, and $\mathrm{H} 5$ are accepted).

\section{Conclusion}

This research discovered a link between human resource and supply chain. In this regard, the primary goal of this research was to examine the impact of human resources on the supply chain, as well as how they influence customer satisfaction and organizational performance.

The results show that human resource management had a direct impact on supply chain and customer satisfaction but there was uncertainty on organization performance. Because various elements must be coupled to boost organization performance, such as finance, product quality, human resource quality, and so on.

To begin with, it is vital to continue to expand marketing to potential markets, enhance international tourists' average spending and length of stay, and lessen reliance on the international tourist market. In the event that the situation worsens or improves, the government should devise plans to assist businesses that are severely impacted by the Covid-19 epidemic, such as exemptions and reductions in health and social insurance contributions; and lower interest rates on bank loans for businesses that already have solid financial resources but are experiencing temporary cash flow problems.

Enterprises must also come up with proactive strategies to avoid becoming trapped in an unpredictable circumstance, such as sticking to the plan and minimizing airfare. This will not result in more earnings if people are not yet permitted to go or if tourists are uneasy due to disease fears. In addition, after the pandemic has been contained, it will be important to improve the quality of human resources as well as the quality of services provided by businesses to attract more tourists.

\section{References}

Asadi, A., Pool, J. K., \& Jalilvand, M. R. (2014). The effect of perceived price fairness through satisfaction and loyalty on international tourists' price acceptance of Islamic-Iranian art products. Education, Business and Society: Contemporary Middle Eastern Issues, 7(4), 201-215.

Berger, S., Lehmann, H., \& Lehner, F. (2002). Location-based services in the tourist industry. Information Technology \& Tourism, 5(4), 243-256.

Buhalis, D., Darcy, S., \& Ambrose, I. (Eds.). (2012). Best practice in accessible tourism: Inclusion, disability, ageing population and tourism. Channel View Publications.

Chen, D. Q., Preston, D. S., \& Swink, M. (2015). How the use of big data analytics affects value creation in supply chain management. Journal of Management Information Systems, 32(4), 4-39.

Corazza, M. V., \& Musso, A. (2021). Urban transport policies in the time of pandemic, and after: An arduous research agenda. Transport Policy, 103, 31-44.

Dinh, T. H. (2017). Tourism supply chain management in the industrial revolution 4.0.

Divisekera, S. (2010). Economics of tourist's consumption behaviour: Some evidence from Australia. Tourism Management, $31(5), 629-636$.

Garanca, Z., Sobeih, A., \& Zakaria, M. (2008). Revisiting the Role of Code of Conduct in Compliance with CSR Demands in the Supply Chain Management of Electronics Business.

Gefen, D., Rigdon, E. E., \& Straub, D. (2011). Editor's comments: an update and extension to SEM guidelines for administrative and social science research. Mis Quarterly, 35(2), 3-14.

Gimenez, C., Large, R., \& Ventura, E. (2005). SCM research methodologies: employing structural equation modeling. In Research methodologies in supply chain management (pp. 155-170). Physica-Verlag HD.

Gunasekaran, A., Patel, C., \& McGaughey, R. E. (2004). A framework for supply chain performance measurement. International Journal of Production Economics, 87(3), 333-347.

Hazen, B. T., Boone, C. A., Ezell, J. D., \& Jones-Farmer, L. A. (2014). Data quality for data science, predictive analytics, and big data in supply chain management: An introduction to the problem and suggestions for research and applications. International Journal of Production Economics, 154, 72-80.

Hazen, B. T., Overstreet, R. E., \& Boone, C. A. (2015). Suggested reporting guidelines for structural equation modeling in supply chain management research. The International Journal of Logistics Management, 26(3), 627-641.

Hohenstein, N. O., Feisel, E., \& Hartmann, E. (2014). Human resource management issues in supply chain management research. International Journal of Physical Distribution \& Logistics Management, 44(6), 434-463.

Jarad, I. A., Yusof, N. A., \& Shafiei, M. W. M. (2010). The organizational performance of housing developers in Peninsular Malaysia. International Journal of Housing Markets and Analysis, 3(2).

Khondker, B. H., \& Ahsan, T. (2015). Background paper on tourism sector. Background Paper for the 7th Five Year Plan.

Kotler, P. (1999). Marketing management. the millennium edition (Vol. 199). Upper Saddle River, NJ: Prentice Hall.

Krmac, E. V. (2011). Intelligent value chain networks: business intelligence and other ICT tools and technologies in supply/demand chains. In Supply Chain Management-New Perspectives. IntechOpen.

Lakens, D. (2014). Performing high-powered studies efficiently with sequential analyses. European Journal of Social Psychology, 44(7), 701-710. 
Li, S., Ragu-Nathan, B., Ragu-Nathan, T. S., \& Rao, S. S. (2006). The impact of supply chain management practices on competitive advantage and organizational performance. Omega, 34(2), 107-124.

Menon, S. T. (2012). Human resource practices, supply chain performance, and wellbeing. International Journal of Manpower, 33(7), 769-785.

Munizu, M. (2013). The Impact of total quality management practices towards competitive advantage and organizational performance: Case of fishery industry in South Sulawesi Province of Indonesia. Pakistan Journal of Commerce and Social Sciences (PJCSS), 7(1), 184-197.

Palang, D., \& Tippayawong, K. Y. (2019). Performance evaluation of tourism supply chain management: the case of Thailand. Business Process Management Journal, 25(6), 1193-1207.

Pang, K., \& Lu, C. S. (2018). Organizational motivation, employee job satisfaction and organizational performance. Maritime Business Review, 3(1).

Pappas, N. (2017). Effect of marketing activities, benefits, risks, confusion due to over-choice, price, quality and consumer trust on online tourism purchasing. Journal of Marketing Communications, 23(2), 195-218.

Power, D. (2005). Supply chain management integration and implementation: a literature review. Supply chain management: an International Journal, 10(4), 252-263.

Soni, G., \& Kodali, R. (2012). A critical review of empirical research methodology in supply chain management. Journal of Manufacturing Technology Management, 23(6), 753-779.

Smith-Doerflein, K. A., Tracey, M., \& Tan, C. L. (2011). Human resource management and supply chain effectiveness: an exploratory study. International Journal of Integrated Supply Management, 6(3-4), 202-232.

Rizan, M. (2010). Analysis of service quality and customer satisfaction, and its influence on customer loyalty. Iberia, 60(3), 15.

Yilmaz, Y., \& Bititci, U. S. (2006). Performance measurement in tourism: a value chain model. International journal of contemporary hospitality management. Communications, 23(2), 195-218.

Wong, K. K. K. (2013). Partial least squares structural equation modeling (PLS-SEM) techniques using SmartPLS. Marketing Bulletin, 24(1), 1-32.

Zhang, X., Song, H., \& Huang, G. Q. (2009). Tourism supply chain management: A new research agenda. Tourism Management, 30(3), 345-358.

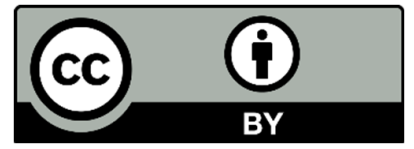

(C) 2021 by the authors; licensee Growing Science, Canada. This is an open access article distributed under the terms and conditions of the Creative Commons Attribution (CCBY) license (http://creativecommons.org/licenses/by/4.0/). 